\title{
Oral administration of Lactococcus chungangensis inhibits 2,4-dinitrochlorobenzene-induced atopic-like dermatitis in NC/Nga mice
}

\author{
Woo Jin Choi,, Maytiya Konkit, ${ }^{*}$ Yena Kim, ${ }^{*}$ Mi-Kyung Kim, $†$ and Wonyong Kim*1 \\ ${ }^{*}$ Department of Microbiology, and \\ †Department of Pathology, Chung-Ang University College of Medicine, 84 Heukseok-ro, Dongjak-gu, Seoul 06974, Republic of Korea
}

\begin{abstract}
Interest is increasing in the potentially beneficial role of probiotics in the prevention and treatment of atopic diseases. In this study, we investigated the protective effects of Lactococcus chungangensis CAU $28^{\mathrm{T}}$ against atopic dermatitis using murine macrophage RAW 264.7 cells, human keratinocyte $\mathrm{HaCaT}$ cells, human mast cell line HMC-1 cells, and a 2,4-dinitrochlorobenzeneinduced atopic dermatitis model (Nc/Nga mice). The results showed that $L$. chungangensis CAU $28^{\mathrm{T}}$ exhibited potent antiinflammatory activity by inhibiting the production of the proinflammatory mediators nitric oxide and prostaglandin $\mathrm{E}_{2}$ in lipopolysaccharide-stimulated RAW 264.7 cells. Treatment with L. chungangensis CAU $28^{\mathrm{T}}$ reduced the release of $\beta$-hexosaminidase and histamine in HMC-1 cells stimulated with mast cell activator compound 48/80. In addition, the back skin and ears of NC/Nga mice exhibited reduced histological manifestations of atopic skin lesions such as erosion, hyperplasia of the epidermis and dermis, and inflammatory cell infiltration. Oral administration of $L$. chungangensis $\mathrm{CAU} 28^{\mathrm{T}}$ suppressed the production of IL-4, IL-5, IL-12, IFN- $\gamma$, tumor necrosis factor- $\alpha$, and thymus- and activation-regulated chemokine (TARC) in skin lesions, indicating that it strongly drives the local immune system with efficacy comparable to that of tacrolimus, a topical immunomodulatory drug used for the treatment of atopic dermatitis. The findings indicate that $L$. chungangensis $\mathrm{CAU} 28^{\mathrm{T}}$ could be a novel probiotic candidate for controlling the symptoms of atopic dermatitis.
\end{abstract}

Key words: Lactococcus, anti-atopic dermatitis, antiinflammatory, antiallergy

Received April 10, 2016

Accepted May 5, 2016.

${ }^{1}$ Corresponding author: kimwy@cau.ac.kr

\section{INTRODUCTION}

Atopic dermatitis (AD) is a multifactorial inflammatory skin disease, with complex interactions of innate and adaptive immune responses, based on pharmacological, immunological, environmental, and psychological predisposition, and that is triggered by a variety of factors (Grewe et al., 1998). Atopic dermatitis induces edema, erythema, itching, skin pigmentation, thickening, eczematous lesions, and excoriation of the skin.

The disease is caused by a combination of genetic and environmental factors. The prevalence of allergy tends to be lower in families with a greater number of siblings. The incidence of allergic disease increases when one moves from a low- to a high-prevalence area and is higher in urban areas than rural areas. These observations highlight the importance of environmental factors in the development of impaired epithelial barrier functions (Williams et al., 1999).

Acute AD skin lesions reveal an important role of the type 2 immune response, characterized by the infiltration of $\mathrm{CD}^{+} \mathrm{T}$ cells and the secretion of IL-4 and IL-5; in contrast, in chronic AD skin lesions, T-helper 1 type immune responses, characterized by the production of IL-12, IFN- $\gamma$, and tumor necrosis factor- $\alpha$ (TNF- $\alpha$ ) by T-helper 1 cells, are involved (Werfel et al., 1996; Grewe et al., 1998; Spergel et al., 1999; Sieling et al., 2003). Thymus- and activation-regulated chemokine (TARC), a chemokine involved in T-helper 2 cell migration, was recently found to be closely associated with AD (Kakinuma et al., 2001; Furusyo et al., 2007). Serum TARC levels were significantly elevated in patients with $\mathrm{AD}$, particularly in those severely affected by the disease, compared with patients with other inflammatory skin diseases and with healthy individuals (Hijnen et al., 2004; Tamaki et al., 2006).

Histamine is a preformed mediator that is stored primarily in the cytoplasmic granules of basophils and mast cells. It is released in response to activation of $\operatorname{IgE}$ receptors on these cell types or by stimulation with degranulating agents, such as complement components, neuropeptides, and cytokines. Production of $\operatorname{IgE}$ is 
closely related to allergic dermatitis and $\mathrm{AD}$, and serum $\mathrm{IgE}$ levels have been reported to be elevated in allergic sensitization and AD patients compared with healthy individuals (Ogawa et al., 1971; Burrows et al., 1989).

Recently, 2,4-dinitrochlorobenzene (DNCB) has been used on the basis of evidence of its efficacy in inducing $\mathrm{AD}$-like skin lesions and IgE hyperproduction in mice models (Kitagaki et al., 1995). 2,4-Dinitrochlorobenzene induces hemorrhages, itching, edema, scarring, dryness, and AD-like skin lesions on the face, nose, ears, neck, and back of BALB/c and NC/Nga mice (Lee et al., 2010; Choi et al., 2012).

Currently, topical corticosteroids are the main therapeutic strategy for treatment of $\mathrm{AD}$; however, they can only be used for a short time and in limited skin regions because of serious adverse effects such as aggravation and recurrence of $\mathrm{AD}$. Among them, tacrolimus ointment, a novel topical immunomodulatory drug, is used for the treatment of $\mathrm{AD}$ in both adults and children. Tacrolimus exerts its therapeutic effect on AD by inhibiting production of proinflammatory cytokines (Nasr, 2000; Reitamo et al., 2000).

Among their potential health-promoting properties, the ability of probiotic bacteria to modulate the host immune system, either by modulating the intestinal microbiota or by direct signaling, is currently an area of intense research. The beneficial role of probiotics in clinical and developmental immunology, especially Bifidobacterium and Lactobacillus strains in AD, has gained significant interest in recent years with both animal studies and human clinical trials (Isolauri et al., 2000; Isolauri, 2001; Kalliomaki et al., 2001; Abrahamsson et al., 2007; Di Felice et al., 2008; Wickens et al., 2008; Bickert et al., 2009). The probiotic therapeutic approach holds great promise for the treatment and prevention of clinical conditions associated with inflammatory and allergic responses (Meneghin et al., 2012).

Lactococci, a member of lactic acid bacteria (LAB), are frequently used in the manufacture of cheese and fermented food products because of their generally recognized as safe (GRAS) status. Moreover, they are assumed incapable of surviving in the gastrointestinal tract. Therefore, previous studies have shown that some lactococcal strains can tolerant a low $\mathrm{pH}$ and a high concentration of bile in the gastrointestinal tract (Kimoto et al., 1999, 2000, 2003). Lactococcus lactis exhibits antipathogen activity through production of bacteriocins and acidification of media (Parente and Ricciardi, 1999). For example, L. lactis C59 was found to improve cytokine balance for preventing IgE-dependent allergic diseases (Yoshida et al., 2011).

Lactococcus chungangensis $\mathrm{CAU} 28^{\mathrm{T}}$, a strain of nondairy origin, was isolated from activated sludge as a sixth member of the genus Lactococcus (Cho et al., 2008). Previously, we have reported that this strain can be applied to the manufacture of dairy products and it has been found to possess functional activities such as alcohol dehydrogenase and aldehyde dehydrogenase, and other enzyme activities such as amylase, proteinase, and lipase (Konkit et al., 2014, 2015, 2016; Konkit and Kim, 2016). However, the effect of L. chungangensis $\mathrm{CAU} 28^{\mathrm{T}}$ on $\mathrm{AD}$ remains to be evaluated. In the present study, we evaluated the antiinflammatory, antiallergic, and anti-AD activities of $L$. chungangensis CAU $28^{\mathrm{T}}$ in relation to the pathogenesis of $\mathrm{AD}$ and compared them with those of with tacrolimus, a routinely used AD drug.

\section{MATERIALS AND METHODS}

\section{Reagents and Materials}

3-(4,5-Dimethylthiazol-2-yl)-2,5- diphenyltetrazolium bromide (MTT) reagent, Griess reagent, dimethyl sulfoxide, mast cell activator compound 48/80 (C48/80), $p$-nitrophenyl- $N$-acetyl- $\beta$-D-glucosaminide, $\mathrm{DNCB}$, and hematoxylin and eosin solution were purchased from Sigma-Aldrich (St. Louis, MO). Dulbecco's modified Eagle's medium (DMEM) and Iscove's modified Dulbecco's medium (IMEM) were purchased from Lonza (Walkersville, MD). Fetal bovine serum and gentamycin were purchased from GIBCO BRL (Grand Island, NY). Histamine assay kit was purchased from Cayman Chemical Company (Ann Arbor, MI). Tryptic soy broth was purchased from Difco (Detroit, MI).

\section{Bacterial Culture}

Lactococcus chungangensis $\mathrm{CAU} 28^{\mathrm{T}}$ was cultured in tryptic soy broth at $30^{\circ} \mathrm{C}$ for $24 \mathrm{~h}$, and cell density was measured using a microplate reader (Tecan, Männedorf, Switzerland). Bacterial cells were harvested by centrifugation $(5 \mathrm{~min}$ at $10,000 \times g)$, washed twice with sterile PBS (pH 7.4), and resuspended in PBS to obtain a final concentration of $10^{9} \mathrm{cfu} / \mathrm{mL}$.

\section{Cell Culture}

Murine macrophage cell line RAW 264.7, human keratinocyte cell line $\mathrm{HaCaT}$, and human mast cell line HMC-1 were obtained from the Korean Cell Line Bank (Seoul, Korea). The RAW 264.7 cells, HaCaT cells, and HMC-1 cells were grown in DMEM and IMEM containing $10 \%$ fetal bovine serum at $37^{\circ} \mathrm{C}$ in a water-jacketed $5 \% \mathrm{CO}_{2}$ incubator (model 3111, Thermo Fisher Scientific, Waltham, MA). The density and viability of cells 
were measured by standard microscopic observations, using a hemocytometer after staining with trypan blue.

\section{Cell Viability Assay}

Cell viability was determined with $10^{9} \mathrm{cfu} / \mathrm{mL}$ of L. chungangensis CAU $28^{\mathrm{T}}$. The RAW 264.7 cells and $\mathrm{HaCaT}$ cells at a density of $5 \times 10^{5}$ cells/well were seeded in 24 -well plates. After $24 \mathrm{~h}$, the cells were subjected to the MTT assay. Medium was replaced with $500 \mu \mathrm{L}$ of fresh serum-free medium containing $0.5 \mathrm{mg} /$ $\mathrm{mL}$ of MTT. After $30 \mathrm{~min}$ of incubation at $37^{\circ} \mathrm{C}$ in a $5 \% \mathrm{CO}_{2}$ incubator, the MTT reagent containing medium was removed, and the reduced formazan dye was solubilized by adding $500 \mu \mathrm{L}$ of dimethyl sulfoxide to each well. After gentle mixing, absorbance was determined at $590 \mathrm{~nm}$ using a microplate reader.

\section{Nitrite and $\mathrm{PGE}_{2}$ Assay}

The RAW 264.7 cells were plated at a density of 5 $\times 10^{5}$ cells in 24 -well cell culture plates with $1 \mathrm{~mL}$ of culture medium and incubated for $24 \mathrm{~h}$. The cells were treated with $10^{9} \mathrm{cfu} / \mathrm{mL}$ of $L$. chungangensis $\mathrm{CAU} 28^{\mathrm{T}}$ in LPS $(0.1 \mu \mathrm{g} / \mathrm{mL})$ and further incubated for $24 \mathrm{~h}$. The concentration of nitrite generated was measured using the Griess reagent system. Equal volumes of the culture supernatant and Griess reagent were mixed and incubated for $10 \mathrm{~min}$ at room temperature. Absorbance was measured at $540 \mathrm{~nm}$ using a spectrophotometer and compared with a nitrite standard curve to determine the concentration of nitrite in the microplate reader. The level of prostaglandin $\mathrm{E}_{2}\left(\mathbf{P G E}_{\mathbf{2}}\right)$ in RAW 264.7 cell culture medium was determined using an ELISA kit (R\&D Systems, Minneapolis, MN) according to the manufacturer's instructions. Absorbance was determined at $450 \mathrm{~nm}$ by using a microplate reader and compared with a standard curve to determine the level of $\mathrm{PGE}_{2}$ in RAW 264.7 cell culture medium.

\section{Measurement of $\beta$-Hexosaminidase Release and Histamine Assay}

The inhibitory effects of $L$. chungangensis CAU $28^{\mathrm{T}}$ on the release of $\beta$-hexosaminidase from HMC- 1 cells were evaluated by using the following modified method (Chen et al., 2010). First, HMC-1 cells were distributed at a density of $2 \times 10^{6}$ cells in 48 -well cell culture plates, treated with Tyrode's buffer $\left(0.4 \mathrm{mM} \mathrm{NaH}_{2} \mathrm{PO}_{4}\right.$, $1.8 \mathrm{~m} M \mathrm{CaCl}_{2}, 2.7 \mathrm{mM} \mathrm{KCl}, 5.6 \mathrm{~m} M$ glucose, $11.9 \mathrm{~m} M$ $\mathrm{NaHCO}_{3}, 137 \mathrm{mM} \mathrm{NaCl}, \mathrm{pH} 7.2$ ), and incubated with L. chungangensis CAU $28^{\mathrm{T}}\left(10^{9} \mathrm{cfu} / \mathrm{mL}\right)$ for $30 \mathrm{~min}$. Briefly, cells were treated with $6 \mu \mathrm{g} / \mathrm{mL}$ of $\mathrm{C} 48 / 80$ for
$30 \mathrm{~min}$. After $30 \mathrm{~min}$, the degranulation reaction was terminated by placing the cells on ice. To determine the activity of $\beta$-hexosaminidase released from the cells, 20 $\mu \mathrm{L}$ of each sample was incubated with $30 \mu \mathrm{L}$ of $1 \mathrm{~m} M$ $p$-nitrophenyl- $N$-acetyl- $\beta$-D-glucosaminide dissolved in $0.1 M$ citrate buffer, $\mathrm{pH} 4.5$, in a 96 -well plate at $37^{\circ} \mathrm{C}$ for $1 \mathrm{~h}$. The reaction was terminated by adding 0.1 $M \mathrm{Na}_{2} \mathrm{CO}_{3} / 0.1 M \mathrm{NaHCO}_{3}$ buffer. Histamine levels in HMC-1 cells were measured using a histamine assay kit according to the manufacturer's instructions (Cayman Chemical Company). The absorbance was determined at $450 \mathrm{~nm}$ by using a microplate reader.

\section{Animal Experiments}

Female 6-wk-old NC/Nga mice were purchased from Jungang Lab Animal Inc. (Seoul, Korea) and Charles River Japan (Tokyo, Japan). Mice were kept under conventional circumstances, including a 12-h light:12-h dark cycle, and food and water were freely available. The controlled room was maintained at $22 \pm 2^{\circ} \mathrm{C}$ with humidity of $55 \pm 10 \%$ (Suto et al., 1999; Aioi et al., 2001). The NC/Nga mice were divided into 5 groups (n = 10 per group): (1) control, (2) DNCB, (3) topical application of $L$. chungangensis $\mathrm{CAU} 28^{\mathrm{T}}$, (4) oral administration of $L$. chungangensis CAU $28^{\mathrm{T}}$, and (5) topical application of tacrolimus. All groups except the control group were treated with DNCB to induce AD-like skin lesions; DNCB was applied to the dorsal skin and ears and was dissolved in an acetone:olive oil mixture (3:1, $\mathrm{vol} / \mathrm{vol}$ ). After complete removal of dorsal hair within an area of approximately $10 \mathrm{~cm}^{2}, 200 \mu \mathrm{L}$ of $1 \%$ DNCB solution was applied 3 times per week for 2 wk. In the topical L. chungangensis group, L. chungangensis CAU $28^{\mathrm{T}}\left(10^{9} \mathrm{cfu} /\right.$ mouse $)$ was topically applied to the dorsal skin and ears of NC/Nga mice 8 times for 4 wk. In the oral L. chungangensis group, L. chungangensis CAU $28^{\mathrm{T}}\left(10^{9} \mathrm{cfu} /\right.$ mouse) was administered orally to $\mathrm{NC} / \mathrm{Nga}$ mice 8 times for 4 wk. In the final group, tacrolimus $(100 \mathrm{mg} / \mathrm{kg})$ was applied to the dorsal skin and ears of NC/Nga mice 8 times for 4 wk. All handling and care of animals, and experimental procedures were performed according to the guidelines approved by the Animal Care and Use Committee of Chung-Ang University of Korea.

\section{Evaluation of Skin Severity}

The severity of $\mathrm{AD}$ on the dorsal skin and ear lesions was evaluated after treatment with DNCB for $1 \mathrm{wk}$ (2 times/week). Skin severity scores were defined as the sum of (1) erythema or hemorrhage, (2) dryness or scarring, (3) edema, and (4) erosion or excoriation and 
was scored as 0 (none), 1 (mild), 2 (moderate), and 3 (severe). The total dermatitis score was defined as the sum of the individual scores (Kunz et al., 1997). The skin was photographed once a week.

\section{Histopathological Studies}

Tissue lesions were sliced and ear slices were fixed in $10 \%$ (vol/vol) neutral buffered formalin for $24 \mathrm{~h}$. The tissue samples were embedded in paraffin and thin sections ( $5 \mu \mathrm{m}$ thick) were obtained. The sections were stained with hematoxylin and eosin solution, and histopathological changes were examined by light microscopy.

\section{Total Serum IgE}

Total serum IgE levels were measured using an ELISA kit (BD Biosciences, San Diego, CA) according to the manufacturer's instructions. Blood was obtained from $\mathrm{NC} /$ Nga mice and the sera were centrifugally separated at $1,200 \times g$ for $15 \mathrm{~min}$. Absorbance was measured at $450 \mathrm{~nm}$ by using a microplate reader.

\section{Reverse Transcription-PCR}

The expression of mRNA transcripts for chemokines and cytokines in the ear tissue from NC/Nga mice was determined by using reverse transcription-PCR. The primers are listed in Supplementary Table S1 (http:// dx.doi.org/10.3168/jds.2016-11301). The tissue was homogenized, and total RNA was isolated by using the TRI method (MRC, Cincinnati, OH), according to the manufacturer's instructions. The reverse transcription-PCR reaction mixture contained AMVreverse transcriptase, deoxynucleotide triphosphates (Promega, Madison, WI), oligo dT primers, and diethyl pyrocarbonate-treated water; the final volume was 20 $\mu \mathrm{L}$. The mixture was incubated at $42^{\circ} \mathrm{C}$ for $60 \mathrm{~min}$. Thereafter, cDNA were amplified with specific primers for the genes. After $10 \mathrm{~min}$ of incubation at $95^{\circ} \mathrm{C}, \mathrm{PCR}$ amplification was performed for 30 cycles with the following steps: denaturation at $95^{\circ} \mathrm{C}$ for $30 \mathrm{~s}$, annealing at 55 to $65^{\circ} \mathrm{C}$ for $30 \mathrm{~s}$, and extension at $70^{\circ} \mathrm{C}$ for $3 \mathrm{~min}$. The PCR was performed using primers for IL-4, IL-5, IL-12, IFN- $\gamma$, TNF- $\alpha$, TARC, and GAPDH. The sequences of the primers are indicated in Supplementary Table S1. The PCR products were analyzed using the GelDoc XR+ imaging system (BioRad, Hercules, CA).

\section{Serum Levels of Chemokine and Cytokine}

Serum levels of IL-4, IL-5, IL-12, IFN- $\gamma$, TNF- $\alpha$, and TARC were measured using an ELISA kit (R\&D
Systems) according to the manufacturer's instructions. Absorbance was determined at $450 \mathrm{~nm}$ by using a microplate reader and was compared with a standard curve to determine the serum levels of chemokines and cytokines.

\section{Statistical Analysis}

All measurements were conducted 3 times and were expressed as the mean \pm standard error (SE). Statistical analyses of the differences between samples were performed by one-way ANOVA, followed by a post hoc multiple comparison with Duncan test and $t$-test using the predictive analytics software (PASW) statistics package for Windows (SPSS Inc./IBM Corp., Armonk, NY). Differences at $P<0.05$ were considered statistically significant.

\section{RESULTS}

\section{Cytotoxicity}

The RAW 264.7 and HaCaT cells were treated for $24 \mathrm{~h}$ with $10^{9} \mathrm{cfu} / \mathrm{mL}$ of $L$. chungangensis, and cytotoxicity was assessed using the MTT assay. The MTT method is a useful alternative to radioisotopic methods for quantitating macrophage cytotoxicity for actively growing in vitro targets (Ferrari et al., 1990). The MTT assay measures the mitochondrial activity of cells, which is considered indicative of cell viability. Lactococcus chungangensis $\mathrm{CAU} 28^{\mathrm{T}}$ did not exert cytotoxic effects on RAW 264.7 and HaCaT cells, as indicated by the MTT assay after $24 \mathrm{~h}$ of incubation (Supplemental Figure S1; http://dx.doi.org/10.3168/jds.2016-11301).

\section{Effects on LPS-Induced Production of NO and PGE 2}

The inhibitory effects of $L$. chungangensis CAU $28^{\mathrm{T}}$ on the production of nitrite were comparatively evaluated by measuring the levels of nitrite, a stable metabolite of $\mathrm{NO}$, and $\mathrm{PGE}_{2}$ in LPS-stimulated RAW 264.7 cells. Levels of $\mathrm{NO}$ and $\mathrm{PGE}_{2}$ in the cell supernatants were measured by using the Griess assay and ELISA. Lactococcus chungangensis CAU $28^{\mathrm{T}}$ effectively suppressed LPS-induced NO production. Consistent with this observation, L. chungangensis CAU $28^{\mathrm{T}}$ markedly inhibited $\mathrm{PGE}_{2}$ production. The $\mathrm{NO}$ level in LPS-stimulated RAW 264.7 cells exposed to $10^{9} \mathrm{cfu} /$ $\mathrm{mL}$ of L. chungangensis CAU $28^{\mathrm{T}}$ was $30.7 \pm 6.4 \%$ of the control (Figure 1A). Further, $\mathrm{PGE}_{2}$ production in cells exposed to $10^{9} \mathrm{cfu} / \mathrm{mL}$ of $L$. chungangensis CAU $28^{\mathrm{T}}$ was $46.8 \pm 6.1 \%$ of the control (Figure $1 \mathrm{~B}$ ). These results showed that L. chungangensis CAU $28^{\mathrm{T}}$ exerted 
A

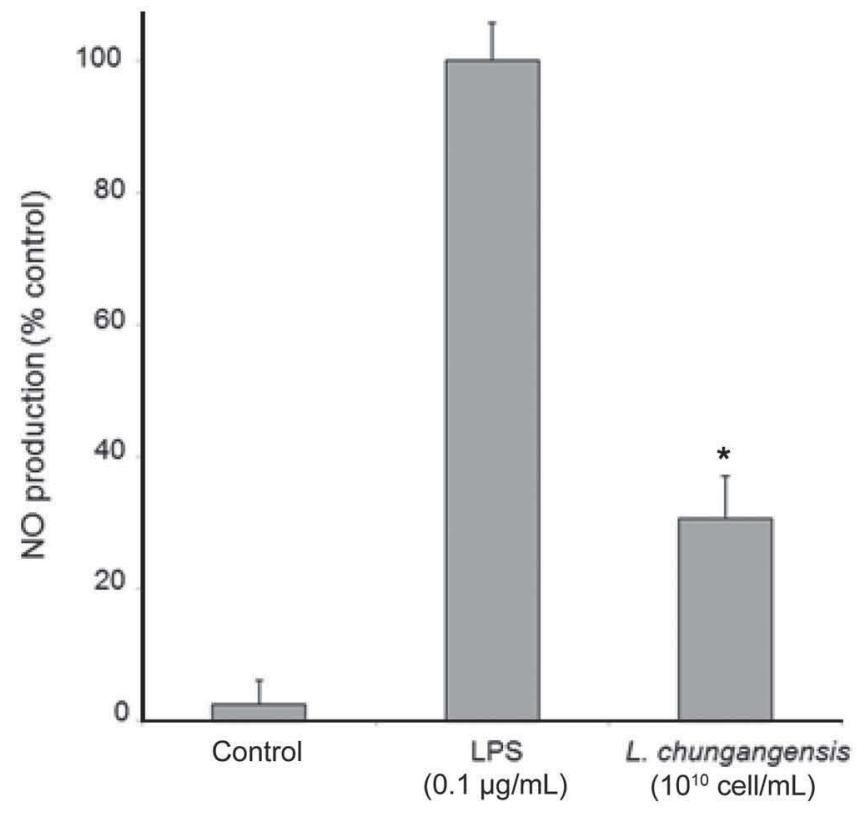

B

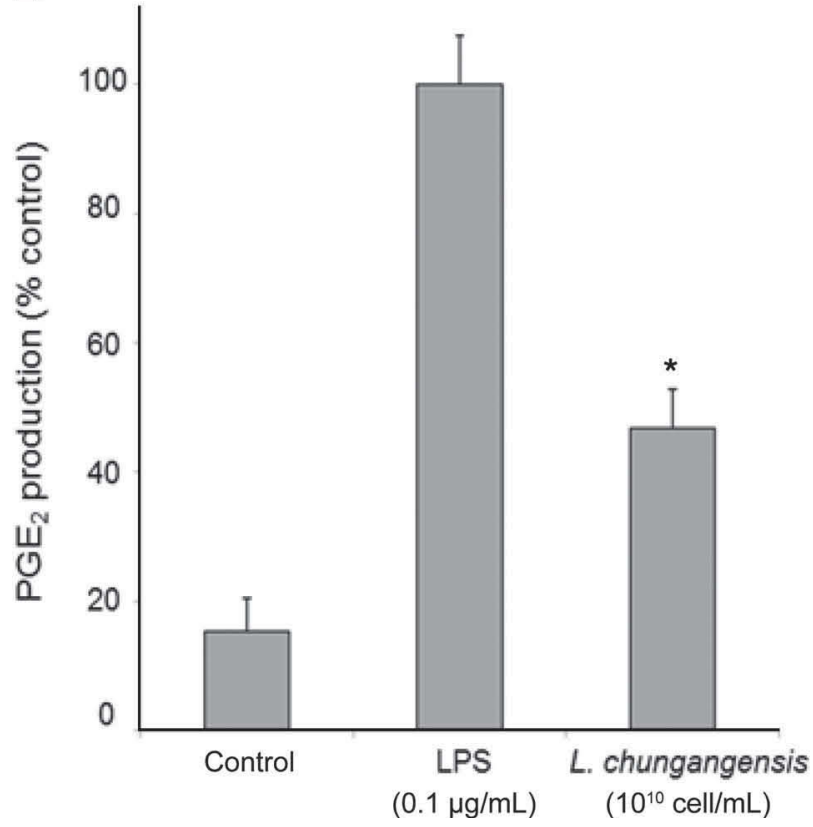

Figure 1. Suppression of LPS-induced production of (A) NO and (B) prostaglandin $\mathrm{E}_{2}\left(\mathrm{PGE}_{2}\right)$ by Lactococcus chungangensis, assessed in the supernatant of RAW 264.7 cells. Error bars represent standard errors. ${ }^{*} P<0.05:$ L. chungangensis treatment compared with LPS (panels $\mathrm{A}$ and $\mathrm{B})$.

an antiinflammatory effect by ameliorating the production of the inflammatory mediators $\mathrm{NO}$ and $\mathrm{PGE}_{2}$.

\section{Effects on $\beta$-Hexosaminidase and Histamine Release}

The release of $\beta$-hexosaminidase was used as a marker of mast cell degranulation to evaluate the antiallergic activity of $L$. chungangensis $\mathrm{CAU} 28^{\mathrm{T}}$ on C48/80-stimulated HMC- 1 cells. The HMC-1 cells $(1 \times$ $10^{6}$ ) and HMC-1 cells pretreated with $L$. chungangensis CAU $28^{\mathrm{T}}$ (at the indicated concentrations) for $30 \mathrm{~min}$ were challenged with $\mathrm{C} 48 / 80(5 \mu \mathrm{g} / \mathrm{mL})$. The release of $\beta$-hexosaminidase was measured as a percentage of the control, and results are shown in Figure 2A. The C48/80-stimulated HMC-1 cells treated with $10^{9} \mathrm{cfu} /$ $\mathrm{mL}$ of $L$. chungangensis $\mathrm{CAU} 28^{\mathrm{T}}$ showed a release of $\beta$-hexosaminidase at a level $35.1 \pm 1.0 \%$ of the control. Thus, L. chungangensis CAU $28^{\mathrm{T}}$ inhibited the release of $\beta$-hexosaminidase (i.e., degranulation) from C48/80induced HMC-1 cells.

Histamine is the best-known pruritogen and is regarded as a primary target for antipruritic therapies. Similar to the inhibitory effect on $\beta$-hexosaminidase release, incubation with $L$. chungangensis CAU $28^{\mathrm{T}}\left(10^{9}\right.$ $\mathrm{cfu} / \mathrm{mL}$ ) for $30 \mathrm{~min}$ before challenge with $\mathrm{C} 48 / 80$ significantly inhibited $(P>0.05)$ the release of histamine. As shown in Figure 2B, the release of histamine from C48/80-stimulated HMC-1 cells exposed to $10^{9} \mathrm{cfu} / \mathrm{mL}$ of L. chungangensis CAU $28^{\mathrm{T}}$ was $19.0 \pm 6.9 \%$ of that of the control, indicating that the allergic responses were effectively diminished by L. chungangensis.

\section{Suppression of DNCB-Induced AD-Like Skin Dermatitis in NC/Nga Mice}

The NC/Nga mice $(\mathrm{n}=50)$ were allocated to each of 5 groups $(\mathrm{n}=10 /$ group): control group, DNCB group, topical application of $L$. chungangensis CAU $28^{\mathrm{T}}$ group, oral administration of L. chungangensis CAU $28^{\mathrm{T}}$ group, and topical application of tacrolimus group. All groups except the control group were treated with DNCB to induce AD-like skin lesions. The DNCB was applied to the dorsal skin and ears. Repeated topical application of DNCB significantly increased AD-like skin symptoms such as hemorrhage, edema, scarring, dryness, and erosion in NC/Nga mice (Figure 3). Repeated topical application of DNCB significantly increased the dermatitis scores and the thickness of the skin or ear in the DNCB-treated group compared with those of the control group. Oral administration of L. chungangensis CAU $28^{\mathrm{T}}$ significantly reduced the severity of DNCBinduced AD-like skin lesions and the thickness of the skin or ear (Figure 4A). The AD-like skin lesions of $\mathrm{NC} / \mathrm{Nga}$ mice were healed with oral administration of L. chungangensis CAU $28^{\mathrm{T}}$, which were similar to that observed with topical application of tacrolimus, relative 
to the control group (Figure 4B). In addition, topical application of L. chungangensis $\mathrm{CAU} 28^{\mathrm{T}}$ resulted in slight reduction of $\mathrm{AD}$ symptoms compared with that of the DNCB group. These results demonstrate that $L$. chungangensis $\mathrm{CAU} 28^{\mathrm{T}}$ was able to decrease $\mathrm{AD}$-like skin symptoms in $\mathrm{NC} / \mathrm{Nga}$ mice.

\section{Suppression of Hyperproduction of IgE}

Although AD has various definitions, it is generally defined by the presence of elevated levels of total and allergen-specific IgE in the serum, leading to positive skin-prick test reactions to common allergens. To examine the effect of $L$. chungangensis $\mathrm{CAU} 28^{\mathrm{T}}$ on production of $\mathrm{IgE}$ in $\mathrm{AD}$-induced $\mathrm{NC} / \mathrm{Nga}$ mice, we performed ELISA to measure serum IgE levels as a diagnostic marker of AD. As shown in Figure 5, serum $\mathrm{IgE}$ levels in the DNCB group were significantly increased $(P<0.05)$ compared with that of the control group, implying that $\mathrm{AD}$ and immune system responses were successfully induced. The IgE level in $\mathrm{NC} / \mathrm{Nga}$ mice subjected to oral administration of L. chungangensis CAU $28^{\mathrm{T}}$ was $16.46 \mathrm{pg} / \mathrm{mL}$, a level similar to that observed with topical application of tacrolimus, which was $14.72 \mathrm{pg} / \mathrm{mL}$. These results indicated that L. chungangensis CAU $28^{\mathrm{T}}$ was effective in suppressing $\mathrm{IgE}$ hyperproduction, and that the level of inhibition was equivalent to that of a commercial $\mathrm{AD}$ treatment.

A

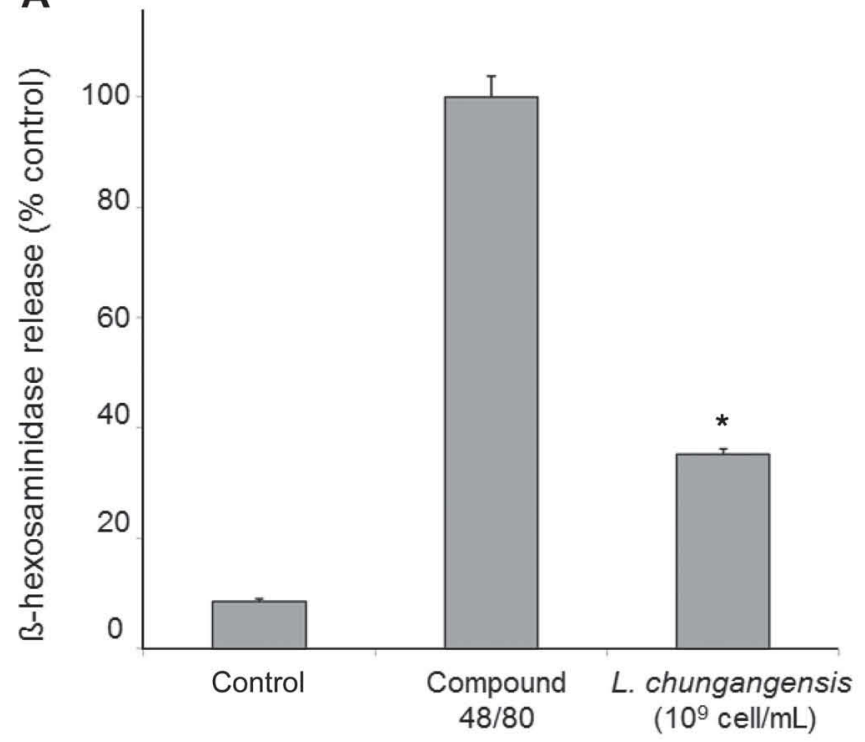

\section{Inhibition of mRNA Expression of Chemokines and Cytokines in Mouse Ear Tissue}

The mRNA expression levels of IL-4, IL-5, IL-12, IFN- $\gamma$, TNF- $\alpha$, and TARC were determined in the control and treatment groups. As shown in Figure 6 , mRNA levels of IL- 4 , IL- 5 , IL-12, IFN- $\gamma$, TNF- $\alpha$, and TARC were enhanced after DNCB treatment in ear tissue of NC/Nga mice. Oral administration of L. chungangensis $\mathrm{CAU} 28^{\mathrm{T}}$ and topical application of tacrolimus dramatically suppressed mRNA expression of IL-4, IL-5, IL-12, IFN- $\gamma$, TNF- $\alpha$, and TARC. The expression levels in $\mathrm{NC} / \mathrm{Nga}$ mice subjected to oral administration of L. chungangensis CAU $28^{\mathrm{T}}$ were similar to that of mice treated with topical application of tacrolimus.

\section{Inhibition of Production of Chemokines and Cytokines}

IL-4, IL-5, and IL-12. Lactococcus chungangensis CAU $28^{\mathrm{T}}$ has the ability to inhibit production of chemokines and cytokines. The IL-4 level in NC/Nga mice subjected to oral administration of $L$. chungangensis CAU $28^{\mathrm{T}}$ was $46.87 \mathrm{pg} / \mathrm{mL}$, which was similar to that obtained with topical application of tacrolimus (44.78 $\mathrm{pg} / \mathrm{mL}$ ). This level was lower than that observed with topical application of $L$. chungangensis CAU $28^{\mathrm{T}}$ and DNCB (Figure 7A). Further, the levels of IL-5 and IL-12 in NC/Nga mice orally administered with $L$.

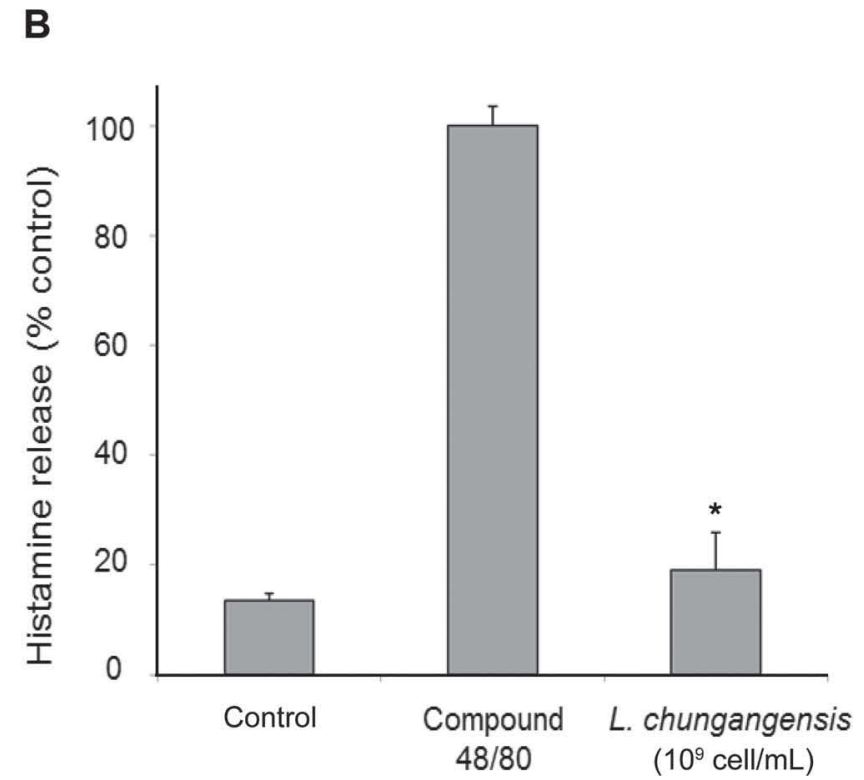

Figure 2. Inhibitory effect of Lactococcus chungangensis CAU $28^{\mathrm{T}}$ on the release of $(\mathrm{A}) \beta$-hexosaminidase and (B) histamine, assessed in the supernatant of mast cell activator compound 48/80-induced HMC-1 cells. Error bars represent standard errors. ${ }^{*} P<0.05:$ L. chungangensis treatment compared with compound 48/80 (panels A and B). 


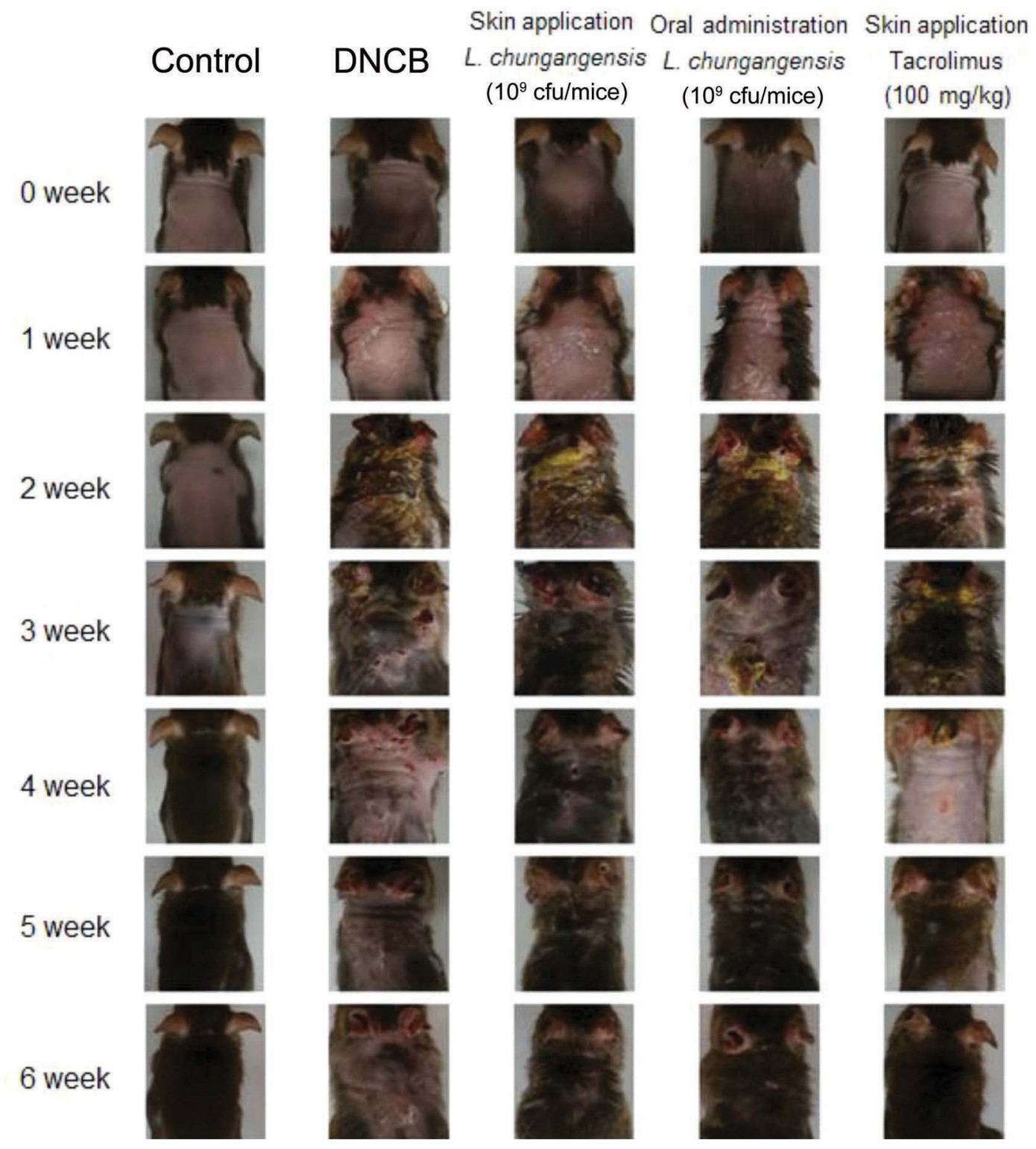

Figure 3. Effects of Lactococcus chungangensis on the symptoms of atopic dermatitis induced by 2,4-dinitrochlorobenzene (DNCB) in NC/ Nga mice (a mouse model cell line for atopic dermatitis). Color version available online.

chungangensis $\mathrm{CAU} 28^{\mathrm{T}}$ were 106.36 and $41.55 \mathrm{pg} / \mathrm{mL}$, respectively. These levels were similar to those resulting from topical application of tacrolimus (98.40 and 40.13 $\mathrm{pg} / \mathrm{mL}$, respectively). In addition, the levels of IL-5 and IL-12 after oral administration of L. chungangensis CAU $28^{\mathrm{T}}$ and topical application of tacrolimus were lower than those with topical application of L. chungangensis $\mathrm{CAU} 28^{\mathrm{T}}$ and DNCB (Figure $7 \mathrm{~B}$ and $7 \mathrm{C}$ ).

IF $N-\gamma, T \boldsymbol{N F}-\alpha$, and TARC. The levels of IFN- $\gamma$, TNF- $\alpha$, and TARC after oral administration of L. chungangensis CAU $28^{\mathrm{T}}$ and topical administration of tacro- limus were lower than those after topical application of L. chungangensis CAU $28^{\mathrm{T}}$ and DNCB. The IFN- $\gamma$ level in NC/Nga mice subjected to oral administration of L. chungangensis CAU $28^{\mathrm{T}}$ was $98.67 \mathrm{pg} / \mathrm{mL}$, which is similar to that with topical application of tacrolimus (93.4 pg/mL) (Figure 7D). Furthermore, the levels of TNF- $\alpha$ and TARC in NC/Nga mice orally administered with $L$. chungangensis CAU $28^{\mathrm{T}}$ were 354.81 and 36.04 $\mathrm{pg} / \mathrm{mL}$, respectively. These levels were similar to those with tacrolimus topical application, which were 351.26 and $33.58 \mathrm{pg} / \mathrm{mL}$, respectively (Figure $7 \mathrm{E}$ and $7 \mathrm{~F}$ ). 
A

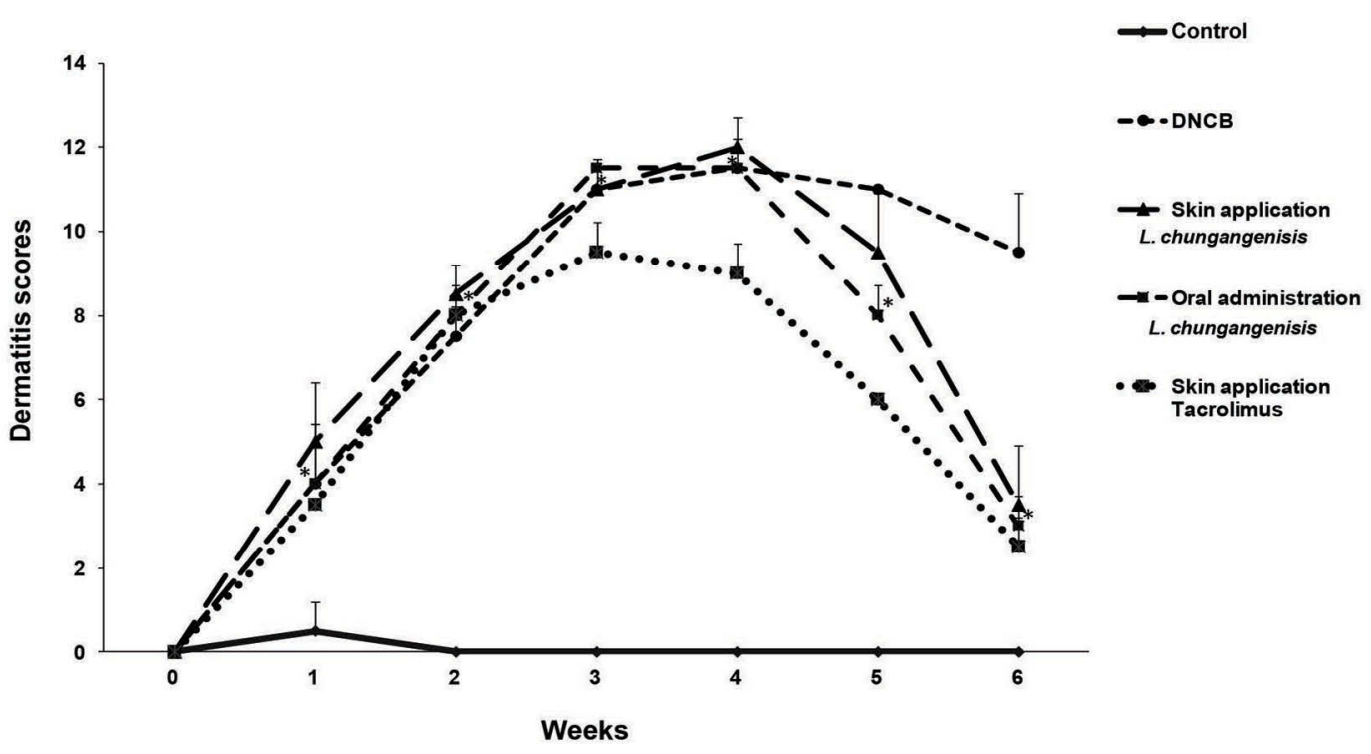

B

Control

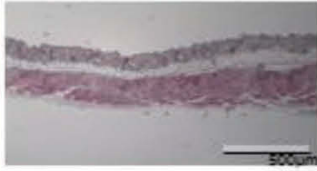

Ear

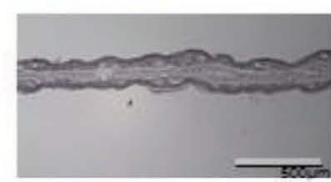

DNCB
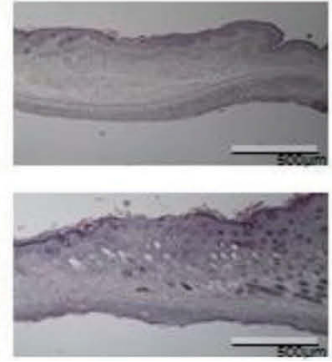

Skin application

$L$. chungangensis

(10 $\left.0^{9} \mathrm{cfu} / \mathrm{mice}\right)$
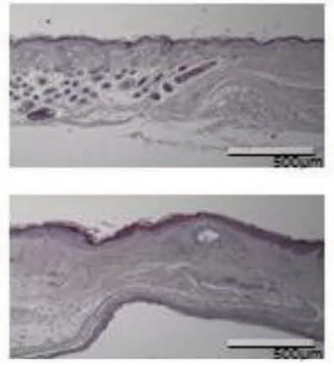

Oral administration

L. chungangensis

( $\left.10^{9} \mathrm{cfu} / \mathrm{mice}\right)$
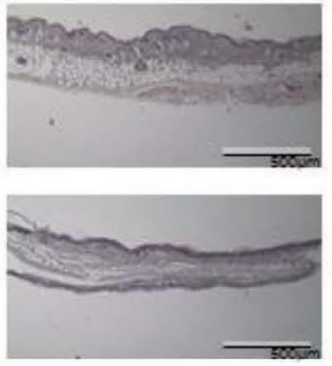

Skin application

Tacrolimus

(100 mg/kg)
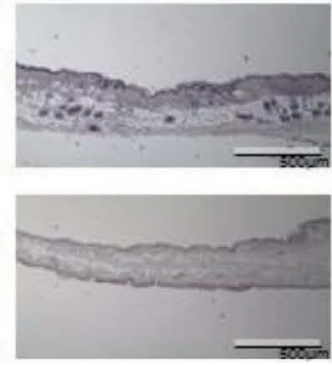

Figure 4. Inhibitory effects of Lactococcus chungangensis CAU $28^{\mathrm{T}}$ on 2,4-dinitrochlorobenzene (DNCB)-induced atopic dermatitis-like skin symptoms in NC/Nga mice (a mouse model cell line for atopic dermatitis). The dermatitis score was defined as the sum of the scores for 7 clinical criteria: erythema, hemorrhage, dryness, scarring, edema, erosion, and excoriation (A); histopathological changes were examined by light microscopy (B). Error bars represent standard errors. ${ }^{*} P<0.05$ : oral administration of L. chungangensis compared with DNCB or skin applications of L. chungangensis or tacrolimus. Color version available online.

\section{DISCUSSION}

Probiotics are live microbial food supplements that are beneficial to human health by maintaining or improving their intestinal microbial balance (Fuller, 1989). Because of these health benefits, the application of probiotic bacteria has increased in dairy products such as yogurt and fermented milk (Saarela et al., 2000). Probiotic bacteria strains must survive in foods to reach the human gastrointestinal system and to further modify gut microbiota. Moreover, an interesting aspect of probiotic bacteria is that they can interact with the host mucosa and may beneficially modulate the immune system (Ziemer and Gibson, 1998; Naidu et al., 1999).

Currently, most probiotic strains belong to the genera Lactobacillus and Bifidobacterium (Smart et al., 1993; Prasad et al., 1998; Grill et al., 2000). However, Lactococcus, Enterococcus, Saccharomyces (Salminen and von Wright, 1998; Kim, 2014), and Propionibacterium (Grant and Salminen, 1998) are also considered as probiotic genera. The LAB exhibit antipathogenic activity through production of bacteriocins and acidification of media (Klaenhammer, 1988; De Vuyst and Leroy, 2007). Lactococcus are LAB that are usually used as starter cultures for the manufacture of cheese and other 
fermented milk products. They have been assumed to be probiotics because they are capable of surviving in the gastrointestinal tract (Kimoto et al., 1999).

Lactococcus chungangensis CAU $28^{\mathrm{T}}$ is the sixth member of the genus Lactococcus and has been found to contain potential functional genes relevant to the dairy industry (Konkit et al., 2014). In addition to genes that are useful for dairy products, L. chungangensis CAU $28^{\mathrm{T}}$ also exhibits alcohol and aldehyde dehydrogenase activity, and reduces blood alcohol and aldehyde levels in mice (Konkit et al., 2015, 2016). However, the anti-AD, antiinflammatory, and antiallergy effect of $L$. chungangensis $\mathrm{CAU} 28^{\mathrm{T}}$ has not been reported previously.

Atopic dermatitis is an inflammatory skin disease provoked by an imbalance between Th1 and Th2 immune response, and it is one of the most common skin lesions in pediatric patients, with a genetic predisposition (Uehara and Kimura, 1993; Stemmler et al., 2007). Atopic dermatitis induces edema, erythema, itching, skin pigmentation, thickening, eczematous lesions, and excoriation of the skin. These symptoms may be accompanied by sleep disturbance and depression and can affect the quality of life (Kiebert et al., 2002; Spergel and Paller, 2003). In addition, AD is frequently associated with food allergy, which complicates its management in approximately $40 \%$ of children (Eigenmann et al., 1998), and it is related to the hyperresponsiveness of lymphocytes to allergens. Furthermore, mast cell degranulation and production of histamine and $\operatorname{Ig} \mathrm{E}$ are closely linked with allergic reactions (Theoharides et al., 2012).

Generally, corticosteroid treatment (creams, ointments, or injections) has been used extensively because it is the most effective therapy for AD (Nakagawa, 2006). Despite their rapid and proven efficiency, corticosteroids can cause various side effects when applied for a long period, such as thinning of the skin, stretch marks, epidermal barrier dysfunction, and immunosuppression (Smith, 2000; Jensen et al., 2011; Berke et al., 2012). Tacrolimus is an example of a topical immunomodulatory ointment used for the treatment of $\mathrm{AD}$ in both adults and children (Kang et al., 2001). Tacrolimus exerts its therapeutic effect by inhibiting the production of proinflammatory cytokines (Nasr, 2000; Reitamo et al., 2000). In addition, tacrolimus has been reported to cause side effects such as headache, paresthesia, tremor, tinnitus, photophobia, blurred vision, gastrointestinal upset, nausea, vomiting, hyperkalemia, hypertension, and hyperuricemia (Atkison et al., 1995). This highlights the urgent need to develop new therapies that target the underlying causes of AD.

This study investigated the antiinflammatory, antiallergy, antibacterial, and anti-AD effects of $L$.

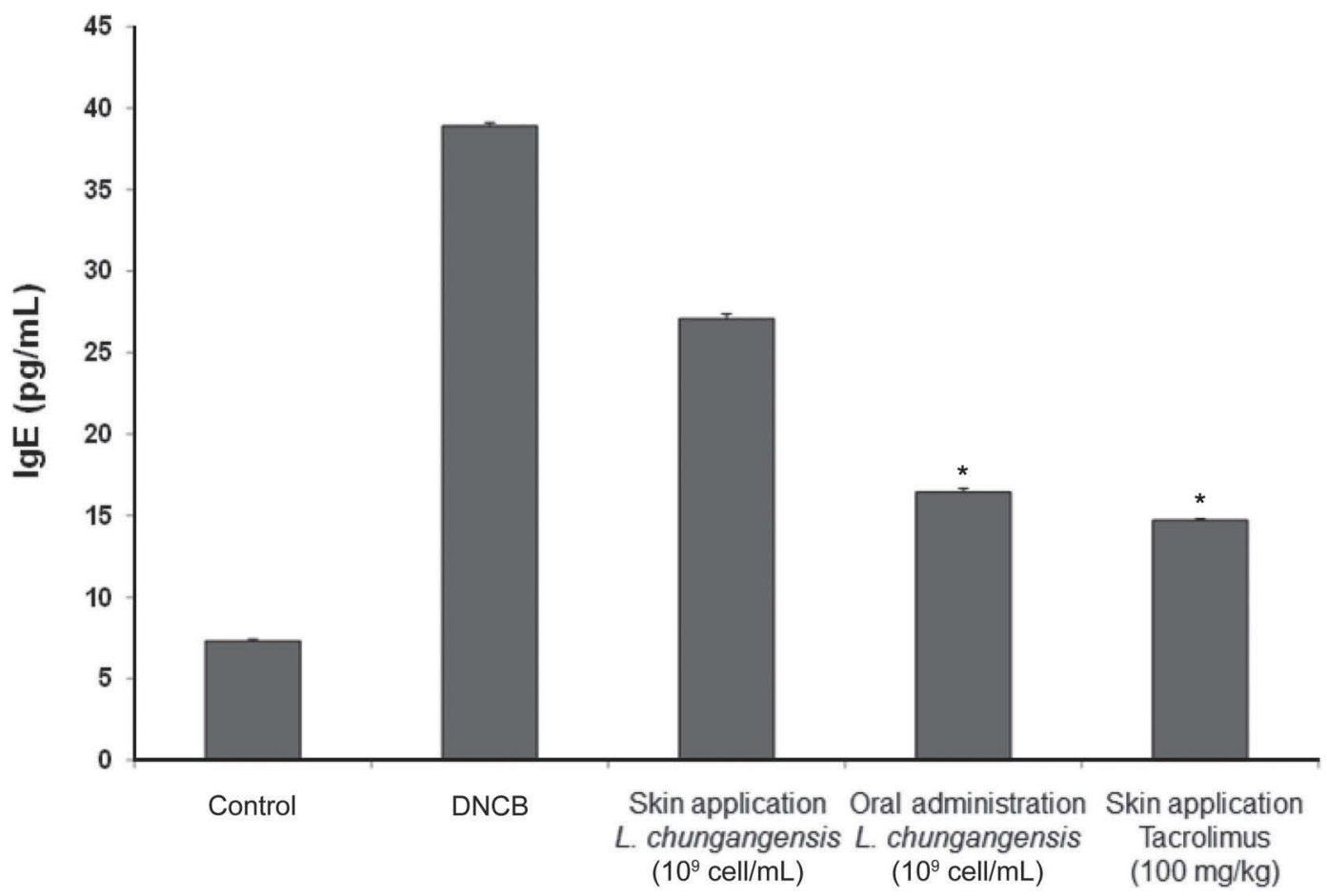

Figure 5. Inhibitory effects of Lactococcus chungangensis CAU $28^{\mathrm{T}}$ on 2,4-dinitrochlorobenzene (DNCB)-induced serum levels of IgE in NC/ Nga mice (a mouse model cell line for atopic dermatitis). Error bars represent standard errors. ${ }^{*} P<0.05$ : oral administration of $L$. chungangensis or skin application of tacrolimus compared with skin application of L. chungangensis or DNCB. 


\section{Control \\ Oral administration \\ L. chungangensis \\ Skin application \\ $\left(10^{9} \mathrm{cfu} / \mathrm{mice}\right)$ \\ Tacrolimus \\ (100 mg/kg)}

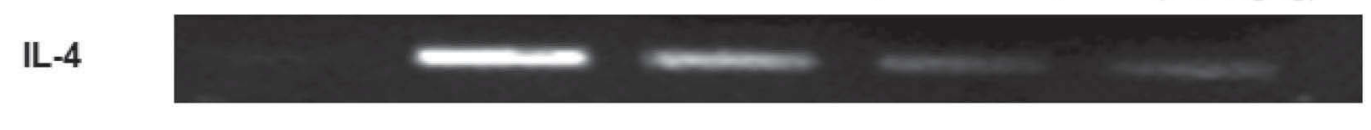

IL-5

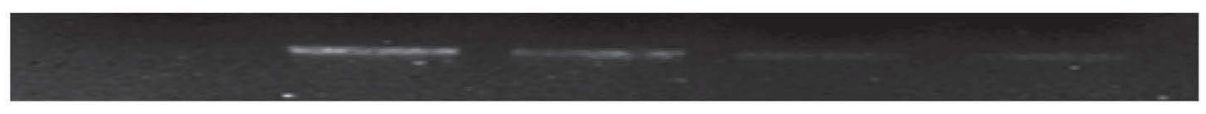

IL-12

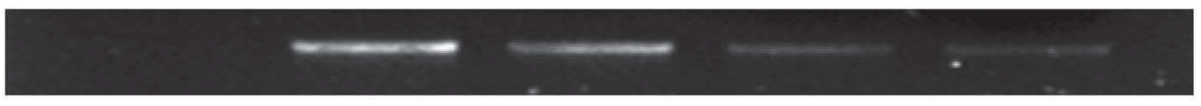

IFN- $\gamma$

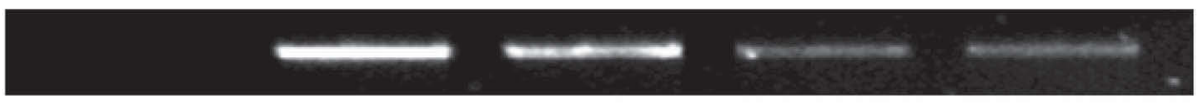

TNF- $\alpha$

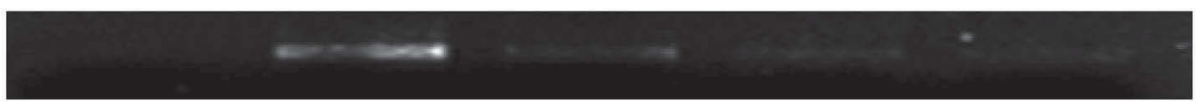

TARC

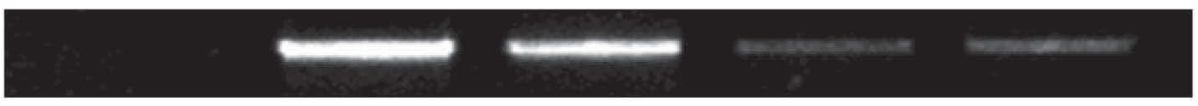

GAPDH

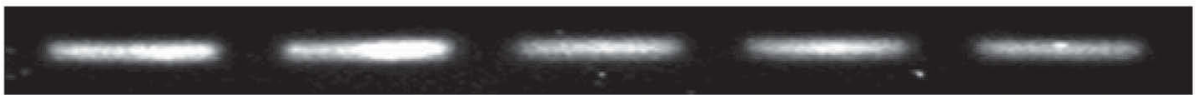

Figure 6. The inhibitory effects of Lactococcus chungangensis CAU $28^{\mathrm{T}}$ on the mRNA expression of chemokines and cytokines in the ear tissue of NC/Nga mice (a mouse model cell line for atopic dermatitis). TNF- $\alpha=$ tumor necrosis factor- $\alpha$; TARC $=$ thymus- and activationregulated chemokine.

chungangensis CAU $28^{\mathrm{T}}$ in murine macrophage cell line RAW 264.7, human keratinocyte cell line HaCaT, human mast cell line HMC-1, and a murine model of DNCB-induced AD. Furthermore, NC/Nga mice were used because of their ability to exhibit characteristics similar to human AD in term of increased serum levels of $\operatorname{IgE}$, chemokines, and cytokines, chronic dryness, and severe pruritus (Jin et al., 2009). After $24 \mathrm{~h}$ of incubation, cytotoxicity of $L$. chungangensis CAU $28^{\mathrm{T}}$ was not observed. Lactococcus chungangensis CAU $28^{\mathrm{T}}$ has shown potential antiinflammatory activity by inhibiting the production of $\mathrm{NO}$ and $\mathrm{PGE}_{2}$, which are proinflammatory mediators, in LPS-stimulated macrophage RAW 264.7 cells (Grahames et al., 1999). In addition, L. chungangensis CAU $28^{\mathrm{T}}$ inhibits the release of $\beta$-hexosaminidase and histamine during mast cell degranulation (Cheong et al., 1998).

In particular, the effect of oral administration of $L$. chungangensis $\mathrm{CAU} 28^{\mathrm{T}}$ was similar to that of topical application of tacrolimus. Oral administration of L. chungangensis $\mathrm{CAU} 28^{\mathrm{T}}$ suppressed the production of IL-4, IL-5, IL-12, IFN- $\gamma$, TNF- $\alpha$, and TARC in skin lesions, which are local immune responses that strongly drive AD. This result is consistent with previous findings (Takahashi et al., 2006; Thomas et al., 2011), which found that the level of IL-4 was significantly lower in mice treated with probiotics than in untreated mice, and that the secretion of proinflammatory cytokines IFN- $\gamma$, TNF- $\alpha$, and IL-12 was reduced.

Most studies have suggested that LAB strains exert an antiallergic effect by regulating the Th1-Th2 balance by inducing IL-12 production. On the other hand, some strains have the potential to suppress antigenspecific IgE production by inducing regulatory $\mathrm{T}$ cells (Ohno et al., 2005; Torii et al., 2007; Nonaka et al., 2008). Consequently, LAB strains have great potential in targeting allergic diseases.

\section{CONCLUSIONS}

The present findings indicate that $L$. chungangensis CAU $28^{\mathrm{T}}$ is a novel therapeutic candidate for an antiatopic agent to reduce AD symptoms. Moreover, the results strongly showed that L. chungangensis CAU $28^{\mathrm{T}}$ 
A
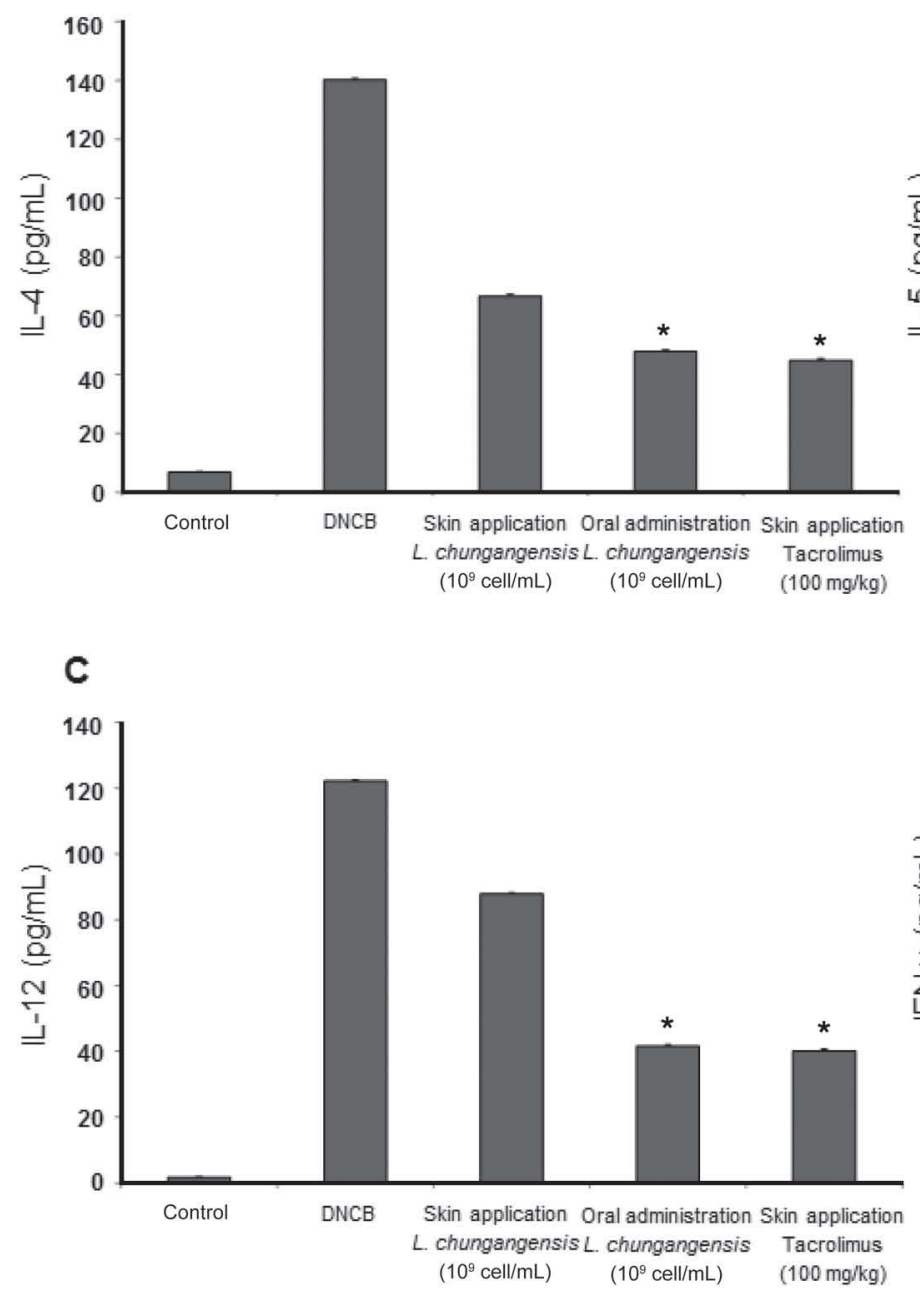

E

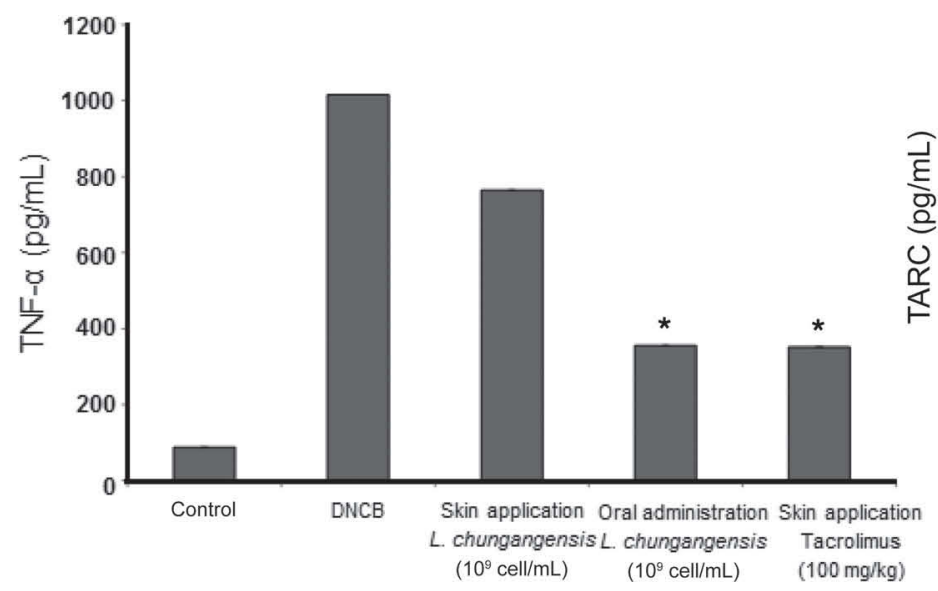

B

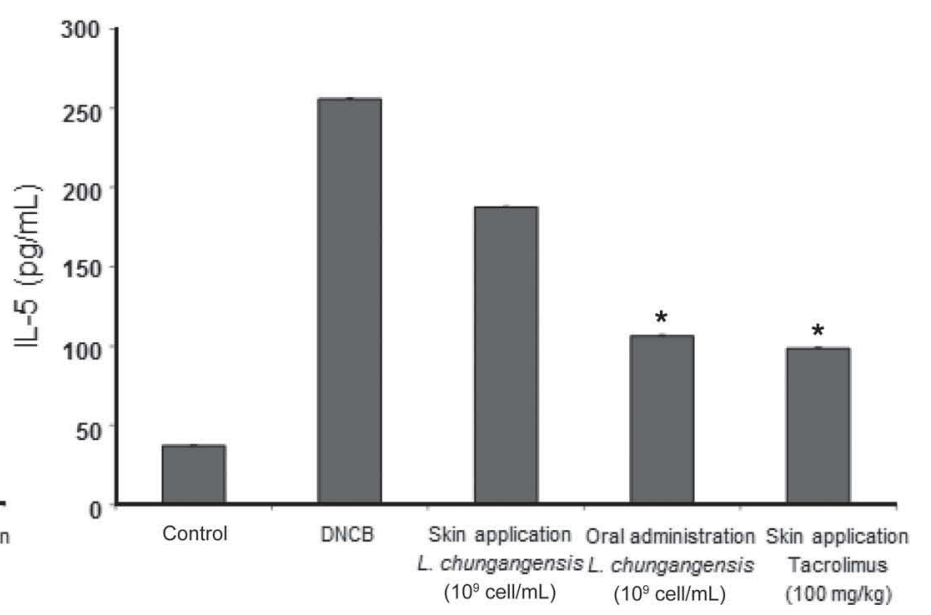

$\mathbf{F}$

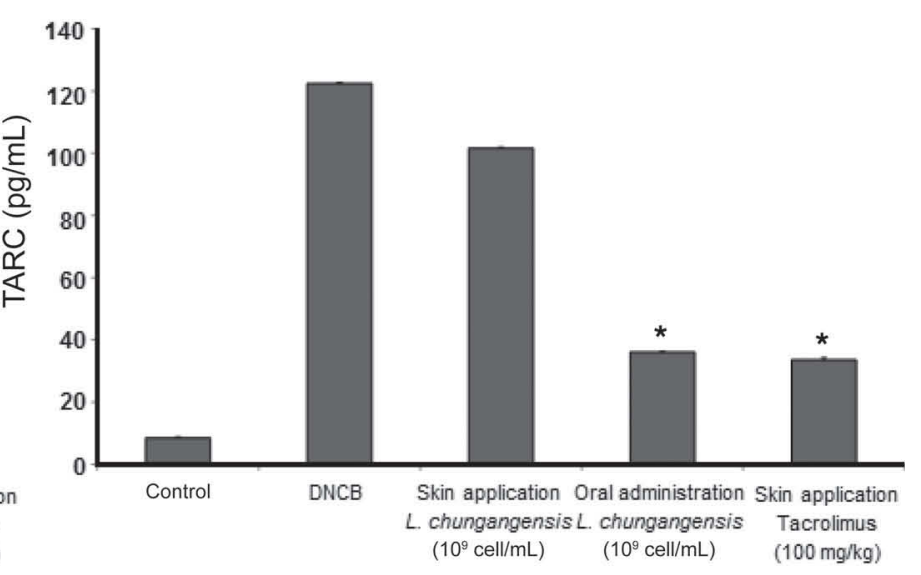

Figure 7. Inhibitory effects of Lactococcus chungangensis CAU $28^{\mathrm{T}}$ on 2,4-dinitrochlorobenzene (DNCB)-induced production of chemokines and cytokines measured in serum obtained from NC/Nga mice (a mouse model cell line for atopic dermatitis): (A) IL-4, (B) IL-5, (C) IL-12, (D) IFN- $\gamma$, (E) tumor necrosis factor- $\alpha$ (TNF- $\alpha$ ), and (F) thymus- and activation-regulated chemokine (TARC). Error bars represent standard errors. ${ }^{*} P<0.05$ : oral administration of $L$. chungangensis or skin application of tacrolimus compared with skin application of $L$. chungangensis or DNCB. 
could inhibit the release of allergy-associated proteins, highlighting its potential as a therapeutic for the prevention of allergic reactions and diseases. Further studies are needed to establish the specificity of this activity and other probiotic benefits in functional dairy foods.

\section{REFERENCES}

Abrahamsson, T. R., T. Jakobsson, M. F. Bottcher, M. Fredrikson, M. C. Jenmalm, B. Bjorksten, and G. Oldaeus. 2007. Probiotics in prevention of IgE-associated eczema: A double-blind, randomized, placebo-controlled trial. J. Allergy Clin. Immunol. 119:1174-1180.

Aioi, A., H. Tonogaito, H. Suto, K. Hamada, C. Ra, H. Ogawa, H. Maibach, and H. Matsuda. 2001. Impairment of skin barrier function in NC/Nga Tnd mice as a possible model for atopic dermatitis. Br. J. Dermatol. 144:12-18.

Atkison, P., G. Joubert, A. Barron, D. Grant, K. Paradis, E. Seidman, W. Wall, H. Rosenberg, J. Howard, S. Williams, and C. Stiller. 1995. Hypertrophic cardiomyopathy associated with tacrolimus in pediatric transplant patients. Lancet 345:894-896.

Berke, R., K. Singh, and M. Guralnick. 2012. Atopic dermatitis: An overview. Am. Fam. Physician 86:35-42.

Bickert, T., C. M. Trujillo-Vargas, M. Duechs, G. Wohlleben, T. Polte, G. Hansen, T. A. Oelschlaeger, and K. J. Erb. 2009. Probiotic Escherichia coli Nissle 1917 suppresses allergen-induced Th2 responses in the airways. Int. Arch. Allergy Immunol. 149:219-230.

Burrows, B., F. D. Martinez, M. Halonen, R. A. Barbee, and M. G. Cline. 1989. Association of asthma with serum IgE levels and skintest reactivity to allergens. N. Engl. J. Med. 320:271-277.

Chen, W. C., I. Beck, W. Schober, K. Brockow, R. Effner, J. T. M. Buters, H. Behrendt, and J. Ring. 2010. Human mast cells express androgen receptors but treatment with testosterone exerts no influence on IgE-independent mast cell degranulation elicited by neuromuscular blocking agents. Exp. Dermatol. 19:302-304.

Cheong, H., E. J. Choi, G. S. Yoo, K.-M. Kim, S. Y. Ryu, and C Ho. 1998. Desacetylmatricarin, an anti-allergic component from Taraxacum platycarpum. Planta Med. 64:577-578.

Cho, S. L., S. W. Nam, J. H. Yoon, J. S. Lee, A. Sukhoom, and W. Kim. 2008. Lactococcus chungangensis sp. nov., a lactic acid bacterium isolated from activated sludge foam. Int. J. Syst. Evol. Microbiol. 58:1844-1849.

Choi, J. H., B. H. Park, H. G. Kim, Y. P. Hwang, E. H. Han, S W. Jin, J. K. Seo, Y. C. Chung, and H. G. Jeong. 2012. Inhibitory effect of Psidium guajava water extract in the development of 2,4-dinitrochlorobenzene-induced atopic dermatitis in NC/Nga mice. Food Chem. Toxicol. 50:2923-2929.

De Vuyst, L., and F. Leroy. 2007. Bacteriocins from lactic acid bacteria: Production, purification, and food applications. J. Mol. Microbiol. Biotechnol. 13:194-199.

Di Felice, G., B. Barletta, C. Butteroni, S. Corinti, R. Tinghino, P. Colombo, and M. Boirivant. 2008. Use of probiotic bacteria for prevention and therapy of allergic diseases-Studies in mouse model of allergic sensitization. J. Clin. Gastroenterol. 42:S130-S132.

Eigenmann, P. A., S. H. Sicherer, T. A. Borkowski, B. A. Cohen, and H. A. Sampson. 1998. Prevalence of IgE-mediated food allergy among children with atopic dermatitis. Pediatrics 101:E8.

Ferrari, M., M. C. Fornasiero, and A. M. Isetta. 1990. MTT colorimetric assay for testing macrophage cytotoxic activity in vitro. J. Immunol. Methods 131:165-172.

Fuller, R. 1989. Probiotics in man and animals. J. Appl. Bacteriol $66: 365-378$.

Furusyo, N., H. Takeoka, K. Toyoda, M. Murat, S. Maeda, H. Ohnishi, H. Uchi, M. Furue, and J. Hayashi. 2007. Thymus and activation regulated chemokines in children with atopic dermatitis: Kyushu University Ishigaki Atopic Dermatitis Study (KIDS). Eur. J. Dermatol. 17:397-404.

Grahames, C. B., A. Michel, I. Chessell, and P. Humphrey. 1999. Pharmacological characterization of ATP-and LPS-induced IL-1ß release in human monocytes. Br. J. Pharmacol. 127:1915-1921.
Grant, C., and S. Salminen. 1998. The potential of Propionibacterium spp. as probiotics. Food Sci. Technol. 1998:588-602.

Grewe, M., C. A. F. M. Bruijnzeel-Koomen, E. Schopf, T. Thepen, A. G. Langeveld-Wildschut, T. Ruzicka, and J. Krutmann. 1998. A role for Th1 and Th2 cells in the immunopathogenesis of atopic dermatitis. Immunol. Today 19:359-361.

Grill, J. P., C. Cayuela, J. Antoine, and F. Schneider. 2000. Isolation and characterization of a Lactobacillus amylovorus mutant depleted in conjugated bile salt hydrolase activity: Relation between activity and bile salt resistance. J. Appl. Microbiol. 89:553-563.

Hijnen, D. J., M. de Bruin-Weller, B. Oosting, C. Lebre, E. de Jong, C. Bruijnzeel-Koomen, and E. Knol. 2004. Serum thymus and activation-regulated chemokine (TARC) and cutaneous T cellattracting chemokine (CTACK) levels in allergic diseases: TARC and CTACK are disease-specific markers for atopic dermatitis. J. Allergy Clin. Immunol. 113:334-340.

Isolauri, E. 2001. Probiotics in human disease. Am. J. Clin. Nutr 73:1142S-1146S.

Isolauri, E., T. Arvola, Y. Sutas, E. Moilanen, and S. Salminen. 2000. Probiotics in the management of atopic eczema. Clin. Exp. Allergy 30:1604-1610.

Jensen, J. M., K. Ahrens, J. Meingassner, A. Scherer, M. Brautigam, A. Stutz, T. Schwarz, R. Folster-Holst, J. Harder, R. Glaser, and E. Proksch. 2011. Differential suppression of epidermal antimicrobial protein expression in atopic dermatitis and in EFAD mice by pimecrolimus compared to corticosteroids. Exp. Dermatol. 20:783-788.

Jin, H., R. He, M. Oyoshi, and R. S. Geha. 2009. Animal models of atopic dermatitis. J. Invest. Dermatol. 129:31-40.

Kakinuma, T., K. Nakamura, M. Wakugawa, H. Mitsui, Y. Tada, H. Saeki, H. Torii, A. Asahina, and K. Tamaki. 2001. Thymus and activation-regulated chemokine (TARC) in atopic dermatitis: Serum level of TARC is closely related with disease activity. J. Invest. Dermatol. 117:463.

Kalliomaki, M., S. Salminen, H. Arvilommi, P. Kero, P. Koskinen, and E. Isolauri. 2001. Probiotics in primary prevention of atopic disease: A randomised placebo-controlled trial. Lancet 357:10761079.

Kang, S., A. W. Lucky, D. Pariser, I. Lawrence, J. M. Hanifin, and T. O. S. Group. 2001. Long-term safety and efficacy of tacrolimus ointment for the treatment of atopic dermatitis in children. J. Am. Acad. Dermatol. 44:S58-S64.

Kiebert, G., S. V. Sorensen, D. Revicki, S. C. Fagan, J. J. Doyle, J. Cohen, and D. Fivenson. 2002. Atopic dermatitis is associated with a decrement in health-related quality of life. Int. J. Dermatol. 41:151-158.

Kim, W. 2014. The genus Lactococcus. Pages 429-443 in Lactic Acid Bacteria: Biodiversity and Taxonomy. W. H. Holzapfel and B. J. B. Wood, ed. Wiley Blackwell, Oxford, UK.

Kimoto, H., J. Kurisaki, N. Tsuji, S. Ohmomo, and T. Okamoto. 1999. Lactococci as probiotic strains: Adhesion to human enterocyte-like Caco-2 cells and tolerance to low pH and bile. Lett. Appl. Microbiol. 29:313-316.

Kimoto, H., M. Nomura, M. Kobayashi, K. Mizumachi, and T. Okamoto. 2003. Survival of lactococci during passage through mouse digestive tract. Can. J. Microbiol. 49:707-711.

Kimoto, H., S. Ohmomo, M. Nomura, M. Kobayashi, and T. Okamoto. 2000. In vitro studies on probiotic properties of lactococci. Milchwissenschaft 55:245-249.

Kitagaki, H., S. Fujisawa, K. Watanabe, K. Hayakawa, and T. Shiohara. 1995. Immediate-type hypersensitivity response followed by a late reaction is induced by repeated epicutaneous application of contact sensitizing agents in mice. J. Invest. Dermatol. 105:749 755 .

Klaenhammer, T. R. 1988. Bacteriocins of lactic-acid bacteria. Biochimie 70:337-349.

Konkit, M., W. J. Choi, and W. Kim. 2015. Alcohol dehydrogenase activity in Lactococcus chungangensis: Application in cream cheese to moderate alcohol uptake. J. Dairy Sci. 98:5974-5982.

Konkit, M., W. J. Choi, and W. Kim. 2016. Aldehyde dehydrogenase activity in Lactococcus chungangensis: Application in cream 
cheese to reduce aldehyde in alcohol metabolism. J. Dairy Sci. 99:1755-1761.

Konkit, M., J.-H. Kim, N. Bora, and W. Kim. 2014. Transcriptomic analysis of Lactococcus chungangensis sp. nov. and its potential in cheese making. J. Dairy Sci. 97:7363-7372.

Konkit, M., and W. Kim. 2016. Activities of amylase, proteinase, and lipase enzymes from Lactococcus chungangensis and its application in dairy products. J. Dairy Sci. 99:4999-5007. http://dx.doi. org/10.3168/jds.2016-11002.

Kunz, B., A. P. Oranje, L. Labreze, J. F. Stalder, J. Ring, and A. Taieb. 1997. Clinical validation and guidelines for the SCORAD index: Consensus report of the European task force on atopic dermatitis. Dermatology 195:10-19.

Lee, S. H., Y. Heo, and Y. C. Kim. 2010. Effect of German chamomile oil application on alleviating atopic dermatitis-like immune alterations in mice. J. Vet. Sci. 11:35-41.

Meneghin, F., V. Fabiano, C. Mameli, and G. V. Zuccotti. 2012. Probiotics and atopic dermatitis in children. Pharmaceuticals (Basel) 5:727-744.

Naidu, A. S., W. Bidlack, and R. Clemens. 1999. Probiotic spectra of lactic acid bacteria (LAB). Crit. Rev. Food Sci. Nutr. 39:13-126.

Nakagawa, H. 2006. Comparison of the efficacy and safety of $0.1 \%$ tacrolimus ointment with topical corticosteroids in adult patients with atopic dermatitis - Review of randomised, double-blind clinical studies conducted in Japan. Clin. Drug Investig. 26:235-246.

Nasr, I. S. 2000. Topical tacrolimus in dermatology. Clin. Exp. Dermatol. 25:250-254.

Nonaka, Y., T. Izumo, F. Izumi, T. Maekawa, H. Shibata, A. Nakano, A. Kishi, K. Akatani, and Y. Kiso. 2008. Antiallergic effects of Lactobacillus pentosus strain S-PT84 mediated by modulation of Th1/Th2 immunobalance and induction of IL-10 production. Int. Arch. Allergy Immunol. 145:249-257.

Ogawa, M., P. A. Berger, O. R. McIntyre, W. E. Clendenning, and K. Ishizaka. 1971. IgE in atopic dermatitis. Arch. Dermatol. 103:575580 .

Ohno, H., S. Tsunemine, Y. Isa, M. Shimakawa, and H. Yamamura 2005. Oral administration of Bifidobacterium bifidum G9-1 suppresses total and antigen specific immunoglobulin E production in mice. Biol. Pharm. Bull. 28:1462-1466.

Parente, E., and A. Ricciardi. 1999. Production, recovery and purification of bacteriocins from lactic acid bacteria. Appl. Microbiol. Biotechnol. 52:628-638.

Prasad, J., H. Gill, J. Smart, and P. K. Gopal. 1998. Selection and characterisation of Lactobacillus and Bifidobacterium strains for use as probiotics. Int. Dairy J. 8:993-1002.

Reitamo, S., A. Wollenberg, E. Schopf, J. L. Perrot, R. Marks, T. Ruzicka, E. Christophers, A. Kapp, M. Lahfa, A. Rubins, S. Jablonska, and M. Rustin. 2000. Safety and efficacy of 1 year of tacrolimus ointment monotherapy in adults with atopic dermatitis. The European Tacrolimus Ointment Study Group. Arch. Dermatol. 136:999-1006.

Saarela, M., G. Mogensen, R. Fondén, J. Mättö, and T. Mattila-Sandholm. 2000. Probiotic bacteria: Safety, functional and technological properties. J. Biotechnol. 84:197-215.

Salminen, S., and A. von Wright. 1998. Current probiotics-safety assured? Microb. Ecol. Health Dis. 10:68-77.

Sieling, P. A., W. Chung, B. T. Duong, P. J. Godowski, and R. L. Modlin. 2003. Toll-like receptor 2 ligands as adjuvants for human Th1 responses. J. Immunol. 170:194-200.

Smart, J. B., C. J. Pillidge, and J. H. Garman. 1993. Growth of lactic acid bacteria and bifidobacteria on lactose and lactose-related mono-, di-and trisaccharides and correlation with distribution of $\beta$-galactosidase and phospho- $\beta$-galactosidase. J. Dairy Res. 60:557-568.

Smith, C. H. 2000. New approaches to topical therapy. Clin. Exp. Dermatol. 25:567-574.

Spergel, J. M., E. Mizoguchi, H. Oettgen, A. K. Bhan, and R. Geha. 1999. Roles of TH1 and TH2 cytokines in a murine model of allergic dermatitis. J. Clin. Invest. 103:1103-1111.

Spergel, J. M., and A. S. Paller. 2003. Atopic dermatitis and the atopic march. J. Allergy Clin. Immunol. 112(Suppl.):S118-S127.

Stemmler, S., Q. Parwez, E. Petrasch-Parwez, J. T. Epplen, and S. Hoffjan. 2007. Two common loss-of-function mutations within the filaggrin gene predispose for early onset of atopic dermatitis. J. Invest. Dermatol. 127:722-724.

Suto, H., H. Matsuda, K. Mitsuishi, K. Hira, T. Uchida, T. Unno, H. Ogawa, and C. Ra. 1999. NC/Nga mice: A mouse model for atopic dermatitis. Int. Arch. Allergy Immunol. 120:70-75.

Takahashi, N., H. Kitazawa, N. Iwabuchi, J. Xiao, K. Miyaji, K. Iwatsuki, and T. Saito. 2006. Immunostimulatory oligodeoxynucleotide from Bifidobacterium longum suppresses Th2 immune responses in a murine model. Clin. Exp. Immunol. 145:130-138.

Tamaki, K., T. Kakinuma, H. Saeki, T. Horikawa, Y. Kataoka, T. Fujisawa, S. Sato, K. Takehara, T. Nakahara, S. Fukagawa, and M. Furue. 2006. Serum levels of CCL17/TARC in various skin diseases. J. Dermatol. 33:300-302.

Theoharides, T. C., K.-D. Alysandratos, A. Angelidou, D.-A. Delivanis, N. Sismanopoulos, B. Zhang, S. Asadi, M. Vasiadi, Z Weng, A. Miniati, and D. Kalogeromitros. 2012. Mast cells and inflammation. Biochim Biophys Acta 1822:21-33. http://dx.doi. org/10.1016/j.bbadis.2010.12.014.

Thomas, D. J., R. J. Husmann, M. Villamar, T. R. Winship, R. H Buck, and F. A. Zuckermann. 2011. Lactobacillus rhamnosus HN001 attenuates allergy development in a pig model. PLoS ONE 6:e16577.

Torii, A., S. Torii, S. Fujiwara, H. Tanaka, N. Inagaki, and H. Nagai. 2007. Lactobacillus acidophilus strain L-92 regulates the production of Th1 cytokine as well as Th2 cytokines. Allergol. Int. 56:293-301.

Uehara, M., and C. Kimura. 1993. Descendant family history of atopic dermatitis. Acta Derm. Venereol. 73:62-63.

Werfel, T., A. Morita, M. Grewe, H. Renz, U. Wahn, J. Krutmann, and A. Kapp. 1996. Allergen specificity of skin-infiltrating T cells is not restricted to a type-2 cytokine pattern in chronic lesions of atopic dermatitis. J. Invest. Dermatol. 107:871-876.

Wickens, K., P. N. Black, T. V. Stanley, E. Mitchell, P. Fitzharris, G. W. Tannock, G. Purdie, and J. Crane., and Probiotic Study Group. 2008. A differential effect of 2 probiotics in the prevention of eczema and atopy: A double-blind, randomized, placebocontrolled trial. J. Allergy Clin. Immunol. 122:788-794.

Williams, H., C. Robertson, A. Stewart, N. Ait-Khaled, G. Anabwani, R. Anderson, I. Asher, R. Beasley, B. Björkstén, and M. Burr. 1999. Worldwide variations in the prevalence of symptoms of atopic eczema in the International Study of Asthma and Allergies in Childhood. J. Allergy Clin. Immunol. 103:125-138.

Yoshida, A., R. Aoki, H. Kimoto-Nira, M. Kobayashi, T. Kawasumi, K. Mizumachi, and C. Suzuki. 2011. Oral administration of live Lactococcus lactis $\mathrm{C} 59$ suppresses IgE antibody production in ovalbumin-sensitized mice via the regulation of interleukin- 4 production. FEMS Immunol. Med. Microbiol. 61:315-322.

Ziemer, C. J., and G. R. Gibson. 1998. An overview of probiotics, prebiotics and synbiotics in the functional food concept: Perspectives and future strategies. Int. Dairy J. 8:473-479. 